\title{
The influence of absorptive capacity and networking capabilities on small and medium enterprises
}

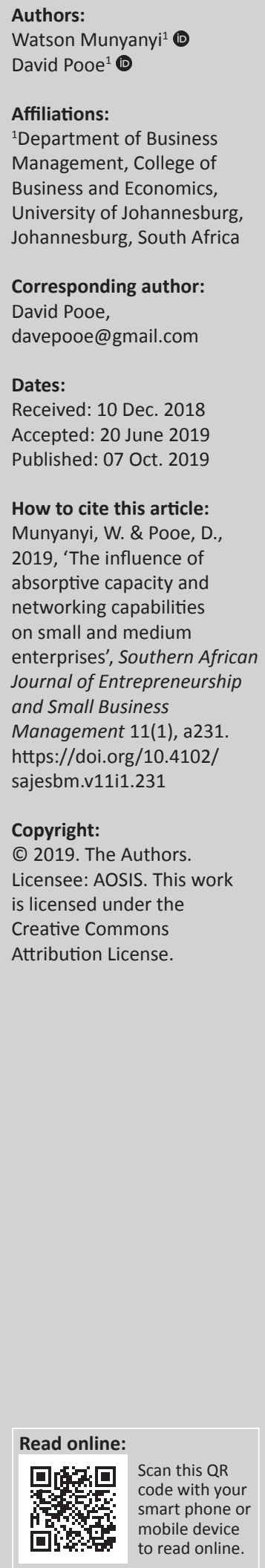

Background: In response to the ever-growing complexity in the business environment that has resulted from the dramatic technological transformation, businesses have altered the way they conduct business. The influence of the external business environment is increasing in significance, rendering traditional methods of operating business outdated and forcing the adoption of new methods.

Objective: The aim of this study is to investigate how organisational capabilities influence small and medium enterprises' (SMEs) operational performance (OP), by specifically looking at absorptive capacity (ACAP), networking capabilities (NCs) and customer relational capabilities (CRCs).

Setting: This study was conducted in Zimbabwe and was spread across the 10 provinces, focusing on 388 randomly selected SMEs.

Methods: Data were collected through self-administering questionnaires to respondents, using the drop-off or pickup technique and making telephonic follow-ups to increase the response rate. Analysis of the data in this study was largely quantitative in nature and it was performed using a two-step structural equation modelling approach.

Results: The results of the study indicate that CRCs lead both ACAP and NCs to improve OP.

Conclusion: This study enlightens both SMEs' managers and policymakers on the significance of capabilities, as opposed to resources, in the growth of the SMEs sector. In light of the results, it is imperative that firms orientate themselves to embrace networking and ACAP as central tenets of their day-to-day operations while attending to customers timely and innovatively.

Keywords: Absorptive capacity; networking capabilities; customer relational capabilities; small- and medium-sized enterprises; SME; dynamic capabilities; dynamic capability theory.

\section{Introduction}

The dramatic technological transformation and the ever-growing complexity in the global business landscape are transforming the way firms must conduct their business to remain competitive (Mu et al. 2017:187). Traditional methods of operating businesses are slowly becoming outdated and irrelevant, forcing firms to adopt new methods and business models. Nowadays, business practitioners must recognise that organisational capabilities are significant in ensuring businesses remain competitive and that such capabilities provide both strategic and competitive advantage to the firm's supply chains and clusters (García-Sánchez, García-Morales \& MartínRojas 2018:354). A firm that possesses competencies or resources but lacks the dynamic capabilities may not be able to make it in the long run because it cannot sustain a sustainable competitive advantage (Augier \& Teece 2009:412; Nason \& Wiklund 2018:32). Altering the business systems is equally important for small and medium enterprises (SMEs), because these are the engines of economic growth both in developed and developing countries and globally. They are sources of innovation and usually respond more quickly to market opportunities than large firms (Coulibaly, Erbao \& Mekongcho 2018:272). Because SMEs lack abundant financial assets to assess their consumer needs effectively, they must rely on organisational capabilities to remain competitive and achieve superior performance (Hsieh \& Chou 2018:84). In this context, investigating the influence of organisational capabilities on operational performance (OP) in the context of SMEs in a developing country is highly relevant. This study sought to examine the effect of both absorptive capacity (ACAP) and networking capabilities (NCs) on SMEs' OP, mediated by customer relational capabilities (CRCs) as a way of bringing the model closer to reality. The study contributes to the construction of existing literature by decomposing NCs and ACAP into four new sub-constructs that enable the identification of the exact source of the influence on OP. It addresses some 
limitations of previous research by linking organisational capabilities to OP as opposed to a more generalised firm performance which other researches have focused on. Given the policy and managerial implications of the subject of organisational capabilities, an appreciation of the relationship between ACAP, NCs as predictors, CRCs as the mediating variable and OP as the outcome variable in SMEs, is necessary for socio-economic transformation.

\section{Literature review}

Over the years, attention and academic interest have increased regarding the notion of organisational capabilities, causing a rise in the approaches to and dimensions of these capabilities (Chong Tan, Mavondo \& Worthington 2011:152). To understand the influence of both ACAP and NCs on the OP of SMEs, it is imperative to understand what SMEs are and what each construct entails.

\section{Small and medium enterprises}

Small and medium enterprises connect with the greater percentage of a country's population, and as a result they have become part of the societies in which they operate (Kato \& Charoenrat 2018:578). In Zimbabwe, as in many developing economies, the number of SMEs has increased drastically over the past three decades, owing to black empowerment and indigenous laws that the country adopted (Nyangara 2013:219). Small and medium enterprises also sprang up to fill the void that was left by large firms that had closed down as a result of the economic meltdown. Research on SMEs in sub-Saharan Africa proves that SMEs account for at least $60 \%$ of the total number of businesses in the economy and contribute to gross domestic product and employment.

Tumwine et al. (2015:74) state that SMEs in Zimbabwe are responsible for $35 \%$ of the gross domestic product and $54 \%$ of the private sector personnel employment. Closer proximity to customers and suppliers tends to give them a competitive edge and degree of flexibility in operations compared to large firms (Sulistyo \& Siyamtinah 2016:196). However, SMEs must be inventive and diligent in creating and solidifying their strategies to sustain their competitive advantage. This is largely because they do not enjoy the economies of scale that large firms enjoy (Patel \& Jayaram 2014:35).

Owners and managers of small and medium enterprises must focus on improving their product offering to levels above their large firm competitors utilising firm-specific knowledge to create effective business processes and routines (Zulu-Chisanga et al. 2016:51).

\section{Absorptive capacity}

One of the most important strategic assets of the firm, which is rooted in the firm's processes, philosophy and human capital, and which is capable of creating additional capabilities and a competitive advantage, is knowledge (Grant 1996:375; Morabito 2013:32). Existing literature has also acknowledged that the fundamental force behind a firm's innovation, survival and growth has been the ability to apply commercial external knowledge, often referred to as ACAP. According to Escribano, Fosfuri and Tribó (2009:101), ACAP refers to the set of knowledge-related capabilities entrenched within a firm's routines and strategic processes, including the four dimensions, namely, knowledge acquisition, assimilation, transformation and exploitation. The underlying notion behind the ACAP construct is that prior related knowledge determines a firm's ability to remain competitive (Hart, Gilstrap \& Bolino 2016:3986). This is further confirmed in the knowledge-based view of the firm, which is an extension of the resource-based view (RBV) and builds on the central role of knowledge in building a competitive edge. Absorptive capacity of a firm does not play a leading role only in determining the magnitude and range of knowledge flows, but is an important driver of organisational activities (Levi-Jakšić, Radovanović \& Radojičić 2013:254). A firm that fronts new knowledge is highly likely to succeed in responding to market changes, through recombining this knowledge with some market information (Atuahene-Gima, Slater \& Olson 2005:476). The new knowledge relating to a firm's ACAP often has a personal touch to it and must be preserved, implying that a firm must create knowledge repositories that are technology and organisational structure enabled (Naqshbandi \& Jasimuddin 2018:703; Xie, Zou \& Qi 2018:291).

\section{Networking capabilities}

In recent decades, empirical studies have established that interfirm networking and alliances are a strategic tool that can be used to support organisational performance. These network connections with business partners and stakeholders provide the firm with access to vital resources required for a competitive edge and endurance, given the turbulence in the business environment (Cygler \& Sroka 2014:53). Networking capabilities refer to a firm's capacity to identify and create relevant and mutual relationships with business partners with the aim of exchanging critical resources and knowledge for the benefit of the organisation (Bengesi \& Le Roux 2014:190). It is an attractive strategic competence that new ventures should possess to gain access to vital external resources, available through business networks interaction (O'Toole \& McGrath 2018:128). Businesses form part of a network system where they interact commercially with other businesses and in these networks, they exchange goods, roles, ideas, technologies and resources (LaageHellman, Landqvist \& Lind 2018:14). Small and medium enterprises with strong NC are better positioned to exploit their structural positions in the network by gain knowledge and technical information, thereby strengthening their operational and innovation output (Wang, Chen \& Fang 2018:222). Networking has been conceived as a multidimensional concept that involves the coordination of strategic relationships through the use of unique relational skills, partner knowledge and strong communication techniques (Parida \& Örtqvist 2015:281). 
As the ventures grow, their main challenge evolves around strategising on how to maintain established business networks and resource structures in a business network (La Rocca, Ford \& Snehota 2013:1029).

\section{Customer relational capabilities}

Customer relational capabilities are entrenched in the firm's ability to recognise beneficial customers and relational prospects, and to initiate and sustain them using attractive incentives so that it is able to leverage on these relationships for profits (Morgan, Vorhies \& Mason 2009:909; Sigala 2018:2699). In today's turbulent business environment, firms must recognise the centrality of, and invest in, customer relationship management (CRM) as a strategy to manage and develop customer relationships (Ascarza et al. 2018:66). The changing customer demands with regard to the quality and novelty of products exert pressure on firms to reorient themselves towards customers. Traditionally, firms viewed customers explicitly as a source of sales and revenue, but the changes in the business setting have forced firms to acknowledge that customers are the icons that orientate and direct firm's strategies (Kim, Kandampully \& Bilgihan 2018:248). Businesses are progressively becoming aware that concentrating on transacting with customers alone is not enough, but there is a need to create and maintain long-term relationships with each individual customer (Shafique et al. 2015:29). They have been pushed to participate in the search, appeal and retention of new and lost customers, while at the same time cultivating and holding on to their current customers (Soltani \& Navimipour 2016:1052). Hence, to keep pace with competition, SMEs must adjust their operational systems so that they are more flexible towards and compliant with customer expectations (Alshura 2018:264; Mansouri, Singh \& Khan 2018:130). To create sustainable and beneficial customer relationships, businesses need to obtain external knowledge necessary in anticipating the changes in customer needs (Hussain et al. 2018:960). According to Alshura (2018:264), this construct is multifaceted, encompassing customer interface, relationship upgrading and win-back abilities.

\section{Operational performance}

Operational performance relates to the efficiency in the activities undertaken by the firm and such efficiencies relate to production cycle, delivery time, customer satisfaction, inventory management and forecasting accuracy (Acar et al. 2017:707). Owing to the socio-economic globalisation that is coupled with advances in technology, customer expectations have changed drastically, business settings have become more unpredictable and product life cycles have grown shorter.

There are several dimensions of performance that a firm must consider to achieve competitive advantage and organisational success. However, there are three main dimensions of performance that are common in empirical literature which the firm should focus on, namely, financial performance, product performance and OP (Kafetzopoulos \& Psomas 2015:107). Meanwhile, environmental changes have also become impulsive and unpredictable and under such circumstances, a firm must strike a balance between continuity and efficiency to ensure sustained profitability (Maijanen \& Virta 2017:146; Yu, Cadeaux \& Luo 2015:190). Operational performance becomes a core strategic competency necessary for survival and to achieve new competitive positions. Attaining the best firm OP requires superior production, marketing, management and supply-chain agility and an improvement in these may potentially improve the revenue and profits levels (Kenyon, Meixell \& Westfall 2016:336).

\section{Conceptual model and hypothesis development}

This study is rooted in both the dynamic capabilities theory (DCT), which stems from the RBV, and the network theory (NT). According to the DCT, dynamic capabilities are those distinctive competencies that allow firms to respond to changes in the markets and determine the pace at which the firm aligns and realigns its resources to take advantage of the opportunities that arise in the business environment (Teece 2014:8). The NT stipulates that the power of a network lies in its capacity to streamline complex network systems so that the partners in the network can understand better its function as a complete unit (Holme 2015:234). These theories, coupled with a review of literature, led to the development of the conceptual model represented in Figure 1.

\section{Absorptive capacity and customer relational capabilities}

Over the years, knowledge management has been the focus of empirical research, especially in relation to its influence on firm's competitive advantage. The knowledge acquisition and assimilation ability of a firm allows it to obtain vital environmental intelligence, hence they are a dynamic source of firm's competitive advantage (Lee et al. 2016:137). In today's world, where customer needs are constantly changing, the knowledge management dimensions are vital for acquiring, assimilating, transforming and applying customer knowledge to create superior customer relations that are characterised by loyalty (Rakthin, Calantone \& Wang 2016:5571). Absorptive capacity is necessary because it equips a firm to identify and understand external knowledge and how to use it to attract customers and come up with products that meet their expectations (Tzokas et al. 2015:136). The firm's ability to utilise newly gained knowledge effectively to develop new products and processes is limited because it is unable to develop and reconfigure such resources (NajafiTavani et al. 2018:4). It is evident, therefore, that the external knowledge that a firm gains through its ACAP is critical for the development of a firm's CRCs. In addition, the knowledge that the firm acquires about its customers and the processes the firm goes through to retain its customers are invaluable (Cron et al. 2014:480). The arguments presented above lead to the following hypothesis:

$\mathbf{H}_{\mathbf{1}}$ : There is a positive and significant relationship between ACAP and CRCs. 


\section{Networking capabilities and customer relational capabilities}

An organisation's NC has been defined as the firm's capacity to initiate and exploit interfirm alliances to its own strategic advantage. Stronger network management activities will help the firm to clarify customer-specific requirements, upon which the firm can develop solutions ahead of competition (Möller \& Halinen 2017:6). Therefore, NCs enable a firm to progress beyond its traditional catchments, gain and manage new customer relations and ultimately create a superior web of commercial relationships. It is therefore appropriate to conclude that to deliver successfully on customer expectations firms need to steer up their ability to network with their strategic partners (Mu et al. 2017:187). Access to knowledge and information enables a firm to enhance its ability to acquire, assimilate, transform and exploit customer-related knowledge; and for long-term customers, personal knowledge is particularly valuable (Berkhout, Hartmann \& Trott 2010:474; Nguyen, Paswan \& Dubinsky 2018:127). In terms of interactions with customers, SMEs have the upper hand over large firms because generally they have a small and limited customer base. This entails a shorter line of communication with customers, and in most cases the owner knows most customers personally. Therefore, possessing a higher degree of network capability endowment allows SMEs to relate better with the other actors in a business network ( $\mathrm{O}^{\prime}$ Toole \& McGrath 2018:129), hence the following hypothesis:

$\mathbf{H}_{2}$ : There is a positive and significant relationship between NCs and CRCs.

\section{Customer relational capabilities and Operational performance}

Because of the developments in the global market, among them an increase in global competition, firms must constantly refine their capabilities to maintain industrial sustainability and competitiveness (Gutierrez-Gutierrez, Barrales-Molina \& Kaynak 2018:44; Roy, Lampert \& Stoyneva 2018:261). In the contemporary business environment, firms must now deal with an increased number of rival firms, so responding quickly to customer needs and establishing satisfactory relationships with them are critical for maintaining an edge over competition (Chang, Wong \& Fang 2014:146). Empirical research has demonstrated that superior CRM significantly improves the performance of the firm, consequently creating ancillary benefits in the form of improved overall firm performance (Josiassen, Assaf \& Cvelbar 2014:134; Keramati, Mehrabi \& Mojir 2010:1171; Wang \& Kim 2017:21). For instance, customer satisfaction and loyalty are vital ingredients for enhancing several aspects of firm performance such as product performance, thus providing a platform for competitive advantages (Rapp, Trainor \& Agnihotri 2010:1229). Therefore, a firm with solid customer-orientated capabilities is better placed to create value for their customers, and via the customer the firm maximises its value (Landroguez, Castro \& Cepeda-Carrion 2018:1141). Based on these arguments, the following hypothesis is made:

$\mathbf{H}_{3}$ : There is a positive and significant relationship between CRCs and OP.

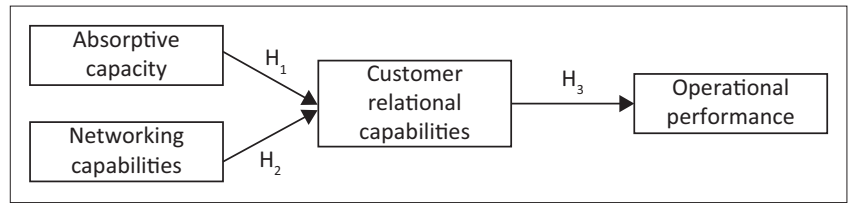

FIGURE 1: Conceptual model.

\section{Methodology}

This study adopted a positivist paradigm, and a quantitative approach to data analysis was mainly used to ensure that the objectives of the study were met. A cross-sectional survey research design was used in the quest to understand the cause-effect relationship between the predictor and outcome variables without experimental manipulation (Babbie \& Mouton 2001:335). This research design was chosen because it allows the researcher to answer the 'what', 'who' and 'how much' research questions (Bryman \& Bell 2015:31).

\section{Study participants}

According to Margaretha and Supartika (2016:132), an SME is an independently owned business entity that holds a relatively small market share, usually managed by its owners or part owners. The main factors distinguishing SMEs from large corporations are the number of employees and the annual turnover (Smit \& Watkins 2012:6325), and these were primarily considered in this study. This study was conducted in Zimbabwe and was spread across the 10 provinces while focusing on SMEs that were listed on the Small and Medium Enterprises Association of Zimbabwe (SMEAZ) website. The SMEAZ is a non-profit-making organisation that champions the cause of SMEs in Zimbabwe, and assists in issues to do with capital formation, training and development. The SMEAZ had in total 1674 SMEs in their online directory available on their website, and these formed the sampling frame. The decision to focus on these SMEs was influenced by the consideration that the SMEs listed are easily observable and have a visible indication of economic activity. Because of the diversity in the sampling frame, the study ended up with a multi-sectoral scope, covering most of the sectors of the economy, including retail, manufacturing, tourism, agriculture and transport. To select the participants, simple random sampling was used, involving random picking of respondents from a sampling frame. This procedure was chosen primarily because it ensures that all the units in the sampling frame have an equal opportunity to be selected. A sample of 837 participants was drawn using the Randomizer software, where each SME was allocated from 1 to 1674 and the software selected numbers randomly. Of the 837 questionnaires distributed, 388 were collected and deemed duly completed to be included for analysis. This study was carried out between 2016 and 2018, and Table 1 shows the demographic characteristics of sample firms.

The profile of respondents in this study, and their firms, showed that most of them were in the retail sector $(26.3 \%)$, which was followed by the manufacturing sector with $21.4 \%$ 
TABLE 1: Demographics of the sample firms.

\begin{tabular}{lcccc}
\hline VaBiable & Frequency & $\mathbf{\%}$ & Valid (\%) & Cumulative (\%) \\
\hline Business sector & & & & \\
Manufacturing & 83 & 21.4 & 21.4 & 21.4 \\
Retail & 102 & 26.3 & 26.3 & 47.7 \\
Mining & 42 & 10.8 & 10.8 & 58.5 \\
Tourism & 52 & 13.4 & 13.4 & 71.9 \\
Agriculture & 47 & 12.1 & 12.1 & 84 \\
Other & 62 & 16.0 & 16.0 & 100 \\
Total & $\mathbf{3 8 8}$ & 100 & 100 & - \\
Number of employees in organisation & & & \\
0-50 & 204 & 52.6 & 52.6 & 52.6 \\
51-100 & 66 & 17 & 17 & 69.6 \\
101-150 & 49 & 12.6 & 12.6 & 82.2 \\
151 and more & 69 & 17.01 & 17.01 & 100 \\
Total & $\mathbf{3 8 8}$ & 100 & 100 & - \\
Business annual turnover & & & & \\
\$0-\$5000 & 145 & 37.4 & 37.4 & 37.4 \\
\$001-\$10 000 & 80 & 20.6 & 20.6 & 58 \\
\$10 000-\$15 000 & 88 & 22.7 & 22.7 & 80.7 \\
\$15 001 and more & 75 & 19.3 & 19.3 & 100 \\
Total & $\mathbf{3 8 8}$ & $\mathbf{1 0 0}$ & $\mathbf{1 0 0}$ & - \\
Years of business operation & & & & \\
Less than 5 years & 164 & 42.3 & 42.3 & 42.3 \\
Between 5 and 10 years & 118 & 30.4 & 30.4 & 72.7 \\
More than 10 years & 106 & 27.3 & 27.3 & 100 \\
\hline Total & $\mathbf{3 8 8}$ & $\mathbf{1 0 0}$ & $\mathbf{1 0 0}$ & - \\
\hline
\end{tabular}

of the total respondents. This data suggests that the most prominent activity in the Zimbabwean economy is retailing, although there is evidence of significant small-scale manufacturing. Around $52.6 \%$ of the responding firms had fewer than 50 employees, while $17.01 \%$ had more than 151 employees. This can be taken as an indicator that firms are keeping operational costs low by streamlining their labour. With regard to annual turnover, 37.4\% (145 firms) were below $\$ 5000.00$, with only $19.3 \%$ indicating that their annual turnover was above $\$ 15000.00$. Finally, the majority of responding firms $(42.3 \%$; 164 firms) had been in business for less than 5 years, while the least number of respondents (106 firms) had had more than 10 years in business.

\section{Measurement instrument and data collection}

In preparation for construct item generation, extensive review of theoretical and empirical literature on organisational capabilities and OP was conducted. Absorptive capacity subconstructs and items were adapted from the work of Tavani, Sharifi and Ismail (2014), and those on NCs were drawn from an instrument by Parida and Örtqvist (2015). Sub-constructs and items were sourced from the work of Yu et al. (2018). The participants were asked four questions per sub-construct, with responses on a five-point Likert scale, ranging from ' $1=$ strongly disagree' to ' $5=$ strongly agree'. In this study, a questionnaire was used as the data collection instrument. A questionnaire is a document that consists of a set of questions designed explicitly for the collection of data from respondents reliably (Bhattacherjee 2012:74). The decision to make use of a questionnaire was motivated by the fact that it is easy to administer, given the many respondents in this study. Because of the study objectives, a questionnaire was deemed suitable for the collection of appropriate research data. Data were collected through self-administering questionnaires to respondents, using the drop-off/pickup technique and making telephonic follow-ups to increase the response rate. This technique is grounded on the Social Exchange Theory, which posits that personal exchanges kindle reciprocity, which improves the likelihood that a respondent will take part in a survey (Dillman, Smyth \& Christian 2014:217). This technique was also chosen because it presented the researcher with an opportunity to explain the research thrust and questions to the respondents, which aided in reducing nonresponses.

\section{Statistical analysis methods}

The analysis of data in this study were largely quantitative in nature and it was performed using a two-step structural equation modelling (SEM) approach. The two-step SEM was adopted in data analysis following the recommendations of Anderson and Gerbing (1988:411), who suggest that a confirmatory factor analysis (CFA) be carried out to test the validity and reliability of the measurement model rigorously before structural path analysis. After the measurement was deemed solid, the structural equation model was then applied to test the acceptability of the research hypotheses. All analyses were conducted using the SPSS 24.0 and AMOS 24.0 statistical packages. According to Nimako, Kwesi and Owusu (2014:42), the use of computer-based statistical packages such as SPSS and AMOS has become critically essential in business and social research because of their ability to process a high volume of data and their speed and level of accuracy in computational analysis when compared to manual systems.

\section{Ethical consideration}

This article followed all ethical standards for a research without direct contact with human or animal subjects.

\section{Results}

\section{Internal consistency and validity of the measurement instrument}

Internal consistency and validity are two essential measures in evaluating measurement instruments. Internal consistency focuses on evaluating the capacity of an instrument to construct measure aspects relating to a construct, while validity relates to the extent to which an instrument measures what it is supposed to measure (Tavakol \& Dennick 2011:51). In a quantitative research, CFA is conducted to confirm reliability and validity. Internal consistency refers to the extent to which the several items relating to a construct correlate (Sekaran \& Bougie 2003:162). Composite reliability (CR) and the Cronbach's $\alpha$ are the tests usually employed to assess internal consistency (Bryman \& Bell 2007:164). The CR statistic informs both on the reliability and internal consistency of a construct. The minimum recommended values for CR scores that indicate reliability and consistency should be over 0.7 (Hair et al. 2010:664). 
Also, a value of 0.7 or more for the $\alpha$ is considered as indicating consistency. More precisely, the generally accepted guiding principles indicate that an $\alpha$ of 0.90 and above indicates high reliability, below 0.90 but above 0.80 moderate reliability and above 0.70 but below 0.80 low reliability (Cronbach 1951:298).

Consequently, the researcher evaluated the reliability of subconstructs separately. The ACAP construct had four subconstructs meant to cover likely dimensions of the construct. This construct showed an $\alpha$ value of 0.831 , which was enough to reflect reliability because it is above the threshold of $\alpha=0.7$. The NC construct also consisted of four sub-constructs and the construct showed a Cronbach's $\alpha=0.882$. The CRC construct, with four sub-constructs, also showed enough internal consistency and at $\alpha=0.843$. The four sub-constructs of OP showed a reliability of $\alpha=0.865$. Overall, enough internal consistency and reliability was confirmed (Table 2).

Convergent validity is measured in terms of the degree to which measures of a specific construct converge a high percentage of variance in common (Ramon-Jeronimo, FlorezLopez \& Ramon-Jeronimo 2017:1503). It explains the extent to which a scale correlates with other measures of the same construct in the same direction. The assessment of convergent validity is done using the $C R$ and average variance extracted (AVE) and a common threshold is CR values greater than 0.7 and AVE values above 0.5 . In this study, all constructs hold acceptable convergent validity, as shown in Table 2, where all CR $(\rho c)$ values are above 0.7 and AVE values above 0.5 , as advocated for by Hair et al. (2017:620). Conventionally, the measurement instrument's discriminant validity is evaluated by comparing the constructs' correlation coefficients and the square root value of AVE. An evaluation of discriminant validity using the examination of the criterion (FornellLarcker 1981:45), showed that the root square of variables' AVE value is higher than the correlation of all constructs. This led to the conclusion that all constructs had enough discriminant validity, implying that the study instrument is valid. Also, once convergent and discriminant validity have been established, the structural model is considered valid for assessment (Hair et al. 2017:629) (Table 3).

\section{Measurement model assessment}

After successfully evaluating the constructs for their contribution to the overall model, it became necessary to evaluate how well the model fits the observed data. The goodness of fit of a measurement model describes how well the model fits a set of observations and typically summarises the variations between observed values. Traditionally, goodness of fit has been evaluated using the chi-square statistic, although it has been criticised for its high sensitivity to the model size, distribution of variables and sample size, creating the possibility of rejecting a valid model erroneously (Bentler \& Bonnet 1980:589).

Fortunately, the chi-square or degrees of freedom ratio in this study was acceptable at 1.968 . The comparative fit index

TABLE 2: First- and second-order confirmatory factor analysis for independent and dependent variables.

\begin{tabular}{|c|c|c|c|c|}
\hline Research construct & Construct item & CR value & AVE value & Factor loading \\
\hline $\begin{array}{l}\text { Absorptive capacity } \\
(\alpha=0.831)\end{array}$ & - & - & - & - \\
\hline \multirow{4}{*}{$\begin{array}{l}\text { Knowledge acquisition } \\
\text { capacity (KAC) }\end{array}$} & KAC1 & 0.764 & 0.547 & 0.705 \\
\hline & - & & & - \\
\hline & KAC3 & & & 0.711 \\
\hline & KAC4 & & & 0.745 \\
\hline \multirow{4}{*}{$\begin{array}{l}\text { Knowledge } \\
\text { assimilation capacity } \\
\text { (AC) }\end{array}$} & $\mathrm{AC} 1$ & 0.801 & 0.502 & 0.811 \\
\hline & - & & & - \\
\hline & $\mathrm{AC2}$ & & & 0.734 \\
\hline & AC3 & & & 0.723 \\
\hline \multirow{4}{*}{$\begin{array}{l}\text { Knowledge } \\
\text { transformation } \\
\text { capability (KTC) }\end{array}$} & KTC1 & 0.748 & 0.538 & 0.742 \\
\hline & KTC2 & & & 0.769 \\
\hline & KTC3 & & & 0.638 \\
\hline & KTC4 & & & 0.777 \\
\hline \multirow{4}{*}{$\begin{array}{l}\text { Knowledge } \\
\text { exploitation capacity } \\
\text { (KEC) }\end{array}$} & KEC1 & 0.793 & 0.589 & 0.708 \\
\hline & KEC2 & & & 0.692 \\
\hline & KEC3 & & & 0.697 \\
\hline & KEC4 & & & 0.751 \\
\hline $\begin{array}{l}\text { Networking capabilities } \\
(\alpha=0.882)\end{array}$ & - & - & - & - \\
\hline \multirow{4}{*}{$\begin{array}{l}\text { Partnering } \\
\text { proreactiveness (PP) }\end{array}$} & PP1 & 0.803 & 0.505 & 0.689 \\
\hline & PP2 & & & 0.715 \\
\hline & PP3 & & & 0.719 \\
\hline & PP4 & & & 0.719 \\
\hline \multirow{4}{*}{$\begin{array}{l}\text { Relational governance } \\
\text { (RG) }\end{array}$} & RG1 & 0.826 & 0.542 & 0.739 \\
\hline & RG2 & & & 0.747 \\
\hline & RG3 & & & 0.718 \\
\hline & RG4 & & & 0.744 \\
\hline \multirow{4}{*}{$\begin{array}{l}\text { Alliance management } \\
\text { capability (AMC) }\end{array}$} & AMC1 & 0.833 & 0.555 & 0.802 \\
\hline & AMC2 & & & 0.736 \\
\hline & AMC3 & & & 0.7 \\
\hline & AMC4 & & & 0.74 \\
\hline \multirow{4}{*}{$\begin{array}{l}\text { Information-sharing } \\
\text { capability (ISC) }\end{array}$} & ISC1 & 0.835 & 0.559 & 0.799 \\
\hline & ISC2 & & & 0.731 \\
\hline & ISC3 & & & 0.75 \\
\hline & ISC4 & & & 0.71 \\
\hline $\begin{array}{l}\text { Customer relational } \\
\text { capabilities }(\alpha=0.843)\end{array}$ & - & - & - & - \\
\hline \multirow{4}{*}{$\begin{array}{l}\text { Interaction } \\
\text { management capability } \\
\text { (CIMC) }\end{array}$} & CIMC1 & 0.794 & 0.541 & - \\
\hline & CIMC2 & & & 0.765 \\
\hline & CIMC3 & & & 0.744 \\
\hline & CIMC4 & & & 0.739 \\
\hline \multirow{4}{*}{$\begin{array}{l}\text { Relationship upgrading } \\
\text { capability (CRUC) }\end{array}$} & CRUC1 & 0.821 & 0.538 & 0.739 \\
\hline & CRUC2 & & & 0.698 \\
\hline & CRUC3 & & & 0.722 \\
\hline & CRUC4 & & & 0.765 \\
\hline \multirow{4}{*}{$\begin{array}{l}\text { Customer win-back } \\
\text { capability (CWBC) }\end{array}$} & CWBC1 & 0.793 & 0.59 & 0.675 \\
\hline & CWBC2 & & & 0.87 \\
\hline & CWBC3 & & & 0.611 \\
\hline & CWBC4 & & & 0.628 \\
\hline \multirow{4}{*}{$\begin{array}{l}\text { Customer-centric } \\
\text { organisation system } \\
\text { (CCOS) }\end{array}$} & ccos1 & 0.809 & 0.514 & 0.768 \\
\hline & ccos2 & & & 0.712 \\
\hline & ccos3 & & & 0.732 \\
\hline & ccos 4 & & & 0.654 \\
\hline $\begin{array}{l}\text { Operational performance } \\
(\alpha=0.865)\end{array}$ & - & - & - & - \\
\hline \multirow{4}{*}{$\begin{array}{l}\text { Operational flexibility } \\
\text { (OF) }\end{array}$} & OF1 & 0.827 & 0.545 & 0.737 \\
\hline & OF2 & & & 0.767 \\
\hline & OF3 & & & 0.768 \\
\hline & OF4 & & & 0.678 \\
\hline
\end{tabular}


TABLE 2 (Continues...): First- and second-order confirmatory factor analysis for independent and dependent variables.

\begin{tabular}{lcccc}
\hline Research construct & Construct item & CR value & AVE value & Factor loading \\
\hline Product quality (PQ) & PQ1 & 0.827 & 0.545 & 0.735 \\
& PQ2 & & & 0.78 \\
& PQ3 & & & 0.764 \\
& PQ4 & & & 0.67 \\
Delivery time (DT) & DT1 & 0.829 & 0.549 & 0.799 \\
& DT2 & & & 0.712 \\
& DT3 & & & 0.759 \\
Production cost & DT4 & & & 0.69 \\
efficiency (CE) & CE1 & 0.862 & 0.61 & 0.841 \\
& CE2 & & & 0.77 \\
& CE3 & & & 0.798 \\
& CE4 & & & 0.712 \\
\hline
\end{tabular}

Note: $X^{2}=7570.760 ; d f=3846 ; X^{2} / d f=1.968(<2) ; \mathrm{GFI}=0.981(>0.9) ; \mathrm{AGFI}=0.960(>0.9)$ $\mathrm{CFI}=0.952$ (>0.9); RMSEA = $0.050(\leq 0.1)$.

AVE, average variance extracted; $\mathrm{CR}$, composite reliability; $d f$, degrees of freedom; GFI, goodness of fit; AGIF, adjusted goodness of fit; CIF, comparative fit index; RMSEA, root mean goodness of , AGIF, adjusted goodness $\mathrm{F}$, CIF, COmpartive fit index; RMSEA, root mean square eror assimilation capacity; KTC, knowledge transformation capability; KEC, knowledge exploitation capacity; $\mathrm{PP}$, partiering proreactiveness; $R G$, relational governance; AMC, alliance management capability, ISC, information sharing capability, CIMC, interaction management capability; CRUC, relationship upgrading capability; CWBC, customer win-back capability; CCOS, customer-centric organisation system; OF, operational flexibility; PQ, product quality; DT, delivery time; $\mathrm{CE}$, production cost efficiency.

TABLE 3: Means and correlations $(n=388)$.

\begin{tabular}{lcccccc}
\hline Construct & Mean & AVE & (1) & (2) & (3) & (4) \\
\hline ACAP & 4.19 & 0.552 & 0.743 & - & - & - \\
NCs & 3.99 & 0.566 & 0.666 & 0.752 & - & - \\
CRCs & 4.21 & 0.548 & 0.631 & 0.728 & 0.740 & - \\
OP & 3.93 & 0.572 & 0.645 & 0.626 & 0.601 & 0.756 \\
\hline
\end{tabular}

AVE, average; ACAP, absorptive capacity; CRCs, customer relational capabilities; NCS, networking capabilities; $\mathrm{OP}$, operational performance.

Note: Figures in diagonal are values of the square root of the AVE. $p<0.001$.

(CFI) and the root mean square error of approximation (RMSEA) were also employed to evaluate goodness of fit, and additionally to counter the weaknesses of the chi-square or degrees of freedom ratio. The CFI was made popular by Bentler (1990:238) as a modification of the Relative Noncentrality Index (RNI), meant to evade the underestimation of goodness of fit in smaller samples. For fitness to be confirmed, CFI values should range from 0 to 1 with bigger values representing a better model (Hu \& Bentler 1999:3). As such, this model showed satisfactory fit as the CFI value was 0.952 . The RMSEA is a measure that reflects the extent of misfit in a proposed measurement model (Browne \& Cudeck 1993:136).

Root mean square error of approximation values are between 0 and 1 with satisfactory model fit being achieved by an RMSEA value of 0.06 or less (Hu \& Bentler 1999:3). In this study, the RMSEA is 0.050 , hence good. After a series of goodness of fit tests, the model was regarded as fit in terms of its relation to the observed variables.

\section{Structural equation modelling: Hypotheses testing}

In SEM, structural equations are used, and the coefficients that describe the direction and depth of the relationship between the independent and dependent variables are path coefficients (Sharma \& Govindaluri 2014:161). The SEM
TABLE 4: Result of the hypotheses testing.

\begin{tabular}{llcccc}
\hline Hypothesis & Path & $\begin{array}{c}\text { Standard path } \\
\text { coefficient }\end{array}$ & $p$ & $t$ & Test result \\
\hline $\mathrm{H}_{1}$ & $\begin{array}{l}\text { Absorptive capacity } \rightarrow \\
\text { Customer relational } \\
\text { capabilities }\end{array}$ & 0.821 & $*$ & 13.0866 & $\mathrm{H}_{1}$ supported \\
$\mathrm{H}_{2}$ & $\begin{array}{l}\text { Networking capabilities } \rightarrow \\
\text { Customer relational } \\
\text { capabilities }\end{array}$ & 0.435 & $*$ & 10.734 & $\mathrm{H}_{2}$ supported \\
$\mathrm{H}_{3}$ & $\begin{array}{l}\text { Customer relational } \\
\text { capabilities } \rightarrow\end{array}$ & 0.754 & $*$ & 12.720 & $\mathrm{H}_{3}$ supported \\
\hline${ }^{*} p<0.001$. & & & & & \\
\hline
\end{tabular}

framework allows the researcher to test the hypotheses proposed in the conceptual model in a manner that simultaneously corrects dilution caused by unreliability (MacCallum \& Austin 2000:201; Preacher 2006:523), and also offers a broader method for accounting for missing data, thereby ensuring that the results are more reliable (Graafland 2018:275) (Table 4).

The SEM result reveals that ACAP has a positive and significant influence on CRCs $(\beta=0.821, p<0.001)$. These results mean that $H_{1}$ stands accepted because it is supported by empirical evidence. Absorptive capacity is the predictor variable that has the largest impact on CRC. The findings are somewhat consistent with Cron et al. (2014:488), who argue that acquiring knowledge about a firm's customers is central to retaining customers and competitiveness. $\mathrm{H}_{2}$ stipulated that there is a positive and significant relationship between NCs and CRCs. The results of this study confirm this relationship as the path coefficient was 0.435 at the 0.001 level of significance. In a related, but not identical, study, Mu et al. (2017:188) came to similar conclusions that to deliver on customer expectations successfully, firms need to interact and connect with their stakeholders. With regard to the third hypothesis in this study, the path coefficient was 0.754 , indicating that the hypothesis was supported. These results are in tandem with Josiassen et al. (2014:136), who found that superior CRM significantly improves the overall performance of the firm, although the study did not focus on OP.

\section{Conclusion}

From a dynamic capability and a network perspective, this study empirically examined the relationships between ACAP, NCs, CRCs and OP in SMEs. The research findings support the propositions of both the DCT and the NT, which are the theories that underpinned this study. The study increases understanding on the concept of organisational capabilities and particularly their effect on OP in SMEs, a research setting that has partial and inconclusive researches. It therefore partially fills the gap in literature on capabilities and OP. Stemming from the results of SEM, a positive relationship was found between relationships proposed in the conceptual model. Customer relational capabilities lead both ACAP and NCs to improved OP. The theoretical outline that was created aids in concluding that better product quality, cost efficiency, operational flexibility and improved delivery time are a direct result of improved CRCs, which are attained through an engagement of the firm's ACAP and networking abilities. Apparently, a firm with a superior knowledge management 
and NCs is better positioned to improve its CRM skills which in turn, can enhance its OP. When networking and knowledge management capabilities are in the mainstream of the firm's operations and strategy, it manages well its customer relations, leading to superior product quality, productivity, operational flexibility and better delivery. This study enlightens both SMEs' managers and policymakers on the significance of capabilities, as opposed to resources, in the growth of the SMEs' sector. Government ought to introduce programmes that promote owner-managers' capabilities in the utilisation of external knowledge and networks to manage relations with customer relations and achieve superior OP.

\section{Managerial implications}

In general, the success of this study centres the value and practicality of the managerial commendations made. Small and medium enterprises usually do not possess abundant resources to finance growth and must rely on intellectual capital to improve firm performance (McDowell et al. 2018:326). Considering the research findings and conclusions, SME owners and managers are encouraged to recognise and prioritise organisational capabilities as antecedents of better OP. Because SMEs operate in a turbulent business environment, assuming a working model that moves away from resource orientation to one that is powered by a combination of organisational capabilities like NCs and ACAP would lead to improved OP. The rate of response and ability to adjust to market changes will enable SMEs to leverage on the advantages of being small, and innovate to competitiveness (LealRodríguez \& Albort-Morant 2016:40). The overall implication of this is that when managers are faced with a strategic decision-making situation, they must not undermine the significance of organisational capabilities. Small and medium enterprises often heavily invest in intellectual capital through employees and hence can leverage on such investments to improve their operations (Maes \& Sels 2014:143). It is also imperative that SMEs should orient their employees to embrace networking and ACAP as central tenets of their day-to-day operations while attending to customers timeously and innovatively. In addition, managers should come up with tailor-made capabilities indices that will be used to evaluate the level of organisation capabilities appreciation within the firm. These staff appraisal tools will be useful as barometers for the evaluation of the general level of absorptive, networking and CRCs within the firm. Adopting the recommendations from this study will be more advantageous to SMEs in Zimbabwe because the economic situation in the country does not allow them to rely on resource abundancy.

\section{Limitations and future research}

Notwithstanding the theoretical and managerial contributions, the study has its limitations. The study was quantitative in approach and while there are advantages to this approach, it fails to capture some vital aspects such as perceptions and emotions which could have been captured if the approach had been blended with a qualitative approach and techniques such as interviews and content analysis. As such, the study would have attained richness by employing mixed methods, where research methods complement each other, and this is the direction future studies should take. In addition, SEM, which was employed in this study, has been criticised for failing to completely validate causality as it can only propose tentative causal inferences (Graafland 2018:275). These methodological insufficiencies reduce the overall generalisability of the research findings, and to address these limitations, future researches should re-evaluate the relationships in this study using other approaches and techniques. Despite the limitations mentioned, the insights brought about by this study are enough to stimulate further research on organisational capabilities and OP.

\section{Acknowledgements Competing interests}

The authors declare that they have no financial or personal relationships that may have inappropriately influenced them in writing this article.

\section{Author's contributions}

The article is based on W.M.'s PhD thesis. D.P. was the supervisor of the $\mathrm{PhD}$ project.

\section{Funding}

This research received no specific grant from any funding agency in the public, commercial or not-for-profit sectors.

\section{Data availability statement}

Data sharing is not applicable to this article.

\section{Disclaimer}

The views and opinions expressed in this article are those of the authors and do not necessarily reflect the official policy or position of any affiliated agency of the authors.

\section{References}

Acar, M.F., Tarim, M., Zaim, H., Zaim, S. \& Delen, D., 2017, 'Knowledge management and ERP: Complementary or contradictory?', International Journal of Information Management 37(6), 703-712. https://doi.org/10.1016/j.ijinfomgt.2017.05.007

Alshura, M.S., 2018, 'Customer relationship management (CRM) capabilities \& building a sustainable competitive advantage in mobile phone operators in Jordan', International Journal of Business and Management 13(3), 262. https:// doi.org/10.5539/ijbm.v13n3p262

Anderson, J.C. \& Gerbing, D.W., 1988, 'Structural equation modeling in practice: A review and recommended two-step approach', Psychological Bulletin 103(3), 411-423. https://doi.org/10.1037//0033-2909.103.3.411

Ascarza, E., Neslin, S.A., Netzer, O., Anderson, Z., Fader, P.S., Gupta, S. et al., 2018, 'In pursuit of enhanced customer retention management: Review, key issues, and future directions', Customer Needs and Solutions 5(1-2), 65-81. https://doi. org/10.1007/s40547-017-0080-0

Atuahene-Gima, K., Slater, S.F. \& Olson, E.M., 2005, 'The contingent value of responsive and proactive market orientations for new product program performance', Journa of Product Innovation Management 22(6), 464-482. https://doi.org/10.1111/ j.1540-5885.2005.00144.x 
Augier, M. \& Teece, D.J., 2009, 'Dynamic capabilities and the role of managers in business strategy and economic performance', Organization Science 20(2), in business strategy and economic performance',

Babbie, E. \& Mouton, J., 2001, The practice of social research, Oxford University Press, Cape Town.

Bengesi, K.M. \& Le Roux, I., 2014, 'Strategic entrepreneurial response of small and medium enterprises in developing economies', International Journal of Busines and Management 9(2), 153. https://doi.org/10.5539/ijbm.v9n2p153

Bentler, P.M., 1990, 'Comparative fit indexes in structural models', Psychological Bulletin 107(2), 238-246. https://doi.org/10.1037//0033-2909.107.2.238

Bentler, P.M. \& Bonnet, D.C., 1980, 'Significance tests and goodness of fit in the analysis of covariance structures', Psychological Bulletin 88(3), 588-606. https:// doi.org/10.1037//0033-2909.88.3.588

Berkhout, G., Hartmann, D. \& Trott, P., 2010, 'Connecting technological capabilities with market needs using a cyclic innovation model', R\&D Management 40(5) 474-490. https://doi.org/10.1111/j.1467-9310.2010.00618.x

Bhattacherjee, A., 2012, Social science research: Principles, methods, and practices, University of South Florida, South Florida.

Browne, M.W. \& Cudeck, R., 1993, 'Alternative ways of assessing model fit', Sage Focus Editions 154, 136-136.

Bryman, A. \& Bell, E., 2007, Business research methods, Oxford University Press, New York, NY.

Bryman, A. \& Bell, E., 2015, Business research methods, Oxford University Press, New York, NY

Chang, H.H., Wong, K.H. \& Fang, P.W., 2014, 'The effects of customer relationship management relational information processes on customer-based performance', Decision Support Systems 66(1), 146-159. https://doi.org/10.1016/j.dss.2014. 06.010

Chong Tan, Y., Mavondo, F. \& Worthington, S., 2011, 'Organisational capabilities and relationship quality: Performance implications for palm oil processors in Malaysia', Asia Pacific Journal of Marketing and Logistics 23(2), 152-164. https:// Malaysia', Asia Pacific Journal of Marketin
doi.org/10.1108/13555851111120461

Coulibaly, S.K., Erbao, C. \& Mekongcho, T.M., 2018, 'Economic globalization entrepreneurship, and development', Technological Forecasting and Socia Change 127(1), 271-280. https://doi.org/10.1016/j.techfore.2017.09.028
Chand

Cron, W.L., Baldauf, A., Leigh, T.W. \& Grossenbacher, S., 2014, 'The strategic role of the sales force: Perceptions of senior sales executives', Journal of the Academy of Marketing Science 42(5), 471-489. https://doi.org/10.1007/s11747Academy of

Cronbach, L.J., 1951, 'Coefficient alpha and the internal structure of tests', Psychometrika 16(3), 297-334. https://doi.org/10.1007/BF02310555

Cygler, J. \& Sroka, W., 2014, 'Structural pathologies in inter-organizational networks and their consequences', Procedia-Social and Behavioral Sciences 110(24), 52-63. https://doi.org/10.1016/j.sbspro.2013.12.847

Dillman, D.A., Smyth, J.D. \& Christian, L.M., 2014, Internet, phone, mail, and mixed method surveys: The tailored design method, John Wiley, Boston, MA.

Escribano, A., Fosfuri, A. \& Tribó, J.A., 2009, 'Managing external knowledge flows: The moderating role of absorptive capacity', Research Policy 38(1), 96-105. https:// doi.org/10.1016/j.respol.2008.10.022

Fornell, C. \& Larcker, D.F., 1981, 'Structural equation models with unobservable variables and measurement error: Algebra and statistics', Journal of Marketing Research 18(3), 382-388. https://doi.org/10.1177/002224378101800313

García-Sánchez, E., García-Morales, V.J. \& Martín-Rojas, R., 2018, 'Analysis of the influence of the environment, stakeholder integration capability, absorptive capacity, and technological skills on organizational performance through capacity, and technological skills on organizational performance through corporate entrepreneurship', International Entrepreneurship and
Journal 14(2), 345-377. https://doi.org/10.1007/s11365-017-0436-9

Graafland, J.J., 2018, 'Ecological impacts of the ISO14001 certification of small and medium sized enterprises in Europe and the mediating role of networks', Journal of Cleaner Production 174(1), 273-282. https://doi.org/10.1016/j.jclepro.2017. of Clean 10.322

Grant, R.M., 1996, 'Prospering in dynamically-competitive environments: Organizational capability as knowledge integration', Organization Science 7(4) 375-387. https://doi.org/10.1287/orsc.7.4.375

Gutierrez-Gutierrez, L.J., Barrales-Molina, V. \& Kaynak, H., 2018, 'The role of human resource-related quality management practices in new product development: A dynamic capability perspective', International Journal of Operations \& Production Management 38(1), 43-66. https://doi.org/10.1108/IJOPM-07-2016-0387

Hair, J.F., Black, W.C., Babin, B.J., Anderson, R.E. \& Tatham, R.L., 2010, Multivariate data analysis: A global perspective, Pearson Education, New Jersey.

Hair, J.F., Hult, G.T.M., Ringle, C.M., Sarstedt, M. \& Thiele, K.O., 2017, 'Mirror, mirro on the wall: A comparative evaluation of composite-based structural equation modeling methods', Journal of the Academy of Marketing Science 45(5), 616-632. https://doi.org/10.1007/s11747-017-0517-x

Hart, T.A., Gilstrap, J.B. \& Bolino, M.C., 2016, 'Organizational citizenship behavior and the enhancement of absorptive capacity', Journal of Business Research 69(10), 3981-3988. https://doi.org/10.1016/j.jbusres.2016.06.001

Holme, P., 2015, 'Modern temporal network theory: A colloquium', The European Physical Journal B 88(9), 234-267. https://doi.org/10.1140/epjb/e2015-60657-4

Hsieh, Y.H. \& Chou, Y.H., 2018, 'Modeling the impact of service innovation for small and medium enterprises: A system dynamics approach', Simulation Modelling Practice and Theory 82(1), 84-102. https://doi.org/10.1016/j. simpat.2017.12.004
Hu, L.T. \& Bentler, P.M., 1999, 'Cutoff criteria for fit indexes in covariance structure analysis: Conventional criteria versus new alternatives', Structural Equation Modeling: A Multidisciplinary Journal 6(1), 1-55. https://doi. Equation Modeling: A Multidis
org/10.1080/10705519909540118

Hussain, J., Shah, F.A., Rehman, W. \& Khan, Y., 2018, 'Learning orientation and performance: The interaction effect of entrepreneurial orientation', Pakistan Business Review 19(4), 960-977.

Josiassen, A., Assaf, A.G. \& Cvelbar, L.K., 2014, 'CRM and the bottom line: Do all CRM dimensions affect firm performance?', International Journal of Hospitality Management 36(1), 130-136. https://doi.org/10.1016/j.ijhm.2013.08.005

Kafetzopoulos, D. \& Psomas, E., 2015, 'The impact of innovation capability on the performance of manufacturing companies: The Greek case', Journa of Manufacturing Technology Management 26(1), 104-130. https://doi. org/10.1108/JMTM-12-2012-0117

Kato, M. \& Charoenrat, T., 2018, 'Business continuity management of small and medium sized enterprises: Evidence from Thailand', International Journal of Disaster Risk Reduction 27(1), 577-587. https://doi.org/10.1016/j.ijdrr.2017.10.002

Kenyon, G.N., Meixell, M.J. \& Westfall, P.H., 2016, 'Production outsourcing and An empirical study using secondary data', International Journal of Production Economics 171(P3), 336-349. https://doi.org/10.1016/j.ijpe.2015.09.017

Keramati, A., Mehrabi, H. \& Mojir, N., 2010, 'A process-oriented perspective on customer relationship management and organizational performance: An

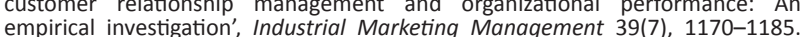
https://doi.org/10.1016/j.indmarman.2010.02.001

Kim, S., Kandampully, J. \& Bilgihan, A., 2018, 'The influence of eWOM communications: An application of online social network framework', Computers in Human Behavior 80(1), 243-254. https://doi.org/10.1016/j.chb.2017.11.015

La Rocca, A., Ford, D. \& Snehota, I., 2013, 'Initial relationship development in new business ventures', Industrial Marketing Management 42(7), 1025-1032. https:// doi.org/10.1016/j.indmarman.2013.07.001

Laage-Hellman, J., Landqvist, M. \& Lind, F., 2018, 'Business creation in networks: How a technology-based start-up collaborates with customers in product development', Industrial Marketing Management 70(1), 13-24. https://doi.org/10.1016/j. indmarman.2017.07.009

Landroguez, S.M., Castro, C.B. \& Cepeda-Carrion, G., 2018, 'Creating dynamic capabilities to increase customer value', Management Decision 56(7), 1141-1660.

Leal-Rodríguez, A. \& Albort-Morant, G., 2016, 'Linking market orientation, innovation and performance: An empirical study on small industrial enterprises in Spain', Journal of Small Business Strategy 26(1), 37-50.

Lee, V.H., Foo, A.T.L., Leong, L.Y. \& Ooi, K.B., 2016, 'Can competitive advantage be achieved through knowledge management? A case study on SMEs', Expert Systems with Applications 65(1), 136-151. https://doi.org/10.1016/j. Expert Systems with

Levi-Jakšić, M., Radovanović, N. \& Radojičić, Z., 2013, 'Absorptive capacity constituents in knowledge-intensive industries in Serbia', Zbornik radova Ekonomskog fakulteta u Rijeci: časopis za ekonomsku teoriju i praksu 31(2), 253-278.

MacCallum, R.C. \& Austin, J.T., 2000, 'Applications of structural equation modeling in psychological research', Annual Review of Psychology 51(1), 201-226.

Maes, J. \& Sels, L., 2014, 'SMEs' radical product innovation: The role of internally and externally oriented knowledge capabilities', Journal of Small Business Management 52(1), 141-163. https://doi.org/10.1111/jsbm.12037

Margaretha, F. \& Supartika, N., 2016, 'Factors affecting profitability of small medium enterprises (SMEs) firm listed in Indonesia Stock Exchange', Journal of Economics, Business and Management 4(2), 132-137.

Maijanen, P. \& Virta, S., 2017, 'Managing exploration and exploitation in a media organisation: A capability-based approach to ambidexterity', Journal of Media
Business Studies 14(2), 146-165. https://doi.org/10.1080/16522354.2017. Business
1290025

Mansouri, A.A.A., Singh, S.K. \& Khan, M., 2018, 'Role of organisational culture, leadership and organisational citizenship behaviour on knowledge management' International Journal of Knowledge Management Studies 9(2), 129-143. https:// International Journal of Knowledge Man
doi.org/10.1504/IJKMS.2018.091249

McDowell, W.C., Peake, W.O., Coder, L. \& Harris, M.L., 2018, 'Building small firm performance through intellectual capital development: Exploring innovation as the "black box"', Journal of Business Research 88(1), 321-327. https://doi. org/10.1016/j.jbusres.2018.01.025

Möller, K. \& Halinen, A., 2017, 'Managing business and innovation networks: From strategic nets to business fields and ecosystems', Industria Marketing Management 67(1), 5-22. https://doi.org/10.1016/j.indmarman. 2017.09.018

Morabito, V., 2013 'Organizational absorptive capacity and the use of information' in V. Morabito (ed.), Business technology organization: Managing Digita Information Technology for Value Creation - The SIGMA Approach, pp. 129-142, Springer, Berlin, Heidelberg.

Morgan, N.A., Vorhies, D.W. \& Mason, C.H., 2009, 'Market orientation, marketing capabilities, and firm performance', Strategic Management Journal 30(8), 909-920. https://doi.org/10.1002/smj.764

Mu, J., Thomas, E., Peng, G. \& Di Benedetto, A., 2017, 'Strategic orientation and new product development performance: The role of networking capability and networking ability', Industrial Marketing Management 64(1), 187-201. https:// doi.org/10.1016/j.indmarman.2016.09.007

Najafi-Tavani, S., Najafi-Tavani, Z., Naudé, P., Oghazi, P. \& Zeynaloo, E., 2018, 'How collaborative innovation networks affect new product performance: Product innovation capability, process innovation capability, and absorptive capacity', Industrial Marketing Management 73(1), 193-205. https://doi.org/10.1016/j. indmarman.2018.02.009 
Naqshbandi, M.M. \& Jasimuddin, S.M., 2018, 'Knowledge-oriented leadership and open innovation: Role of knowledge management capability in France-based
multinationals', International Business Review 27(3), 701-713. https://doi. org/10.1016/j.ibusrev.2017.12.001

Nason, R.S. \& Wiklund, J., 2018, 'An assessment of resource-based theorizing on firm growth and suggestions for the future', Journal of Management 44(1), 32-60. https://doi.org/10.1177/0149206315610635

Nguyen, T.D., Paswan, A. \& Dubinsky, A.J., 2018, 'Allocation of Salespeople's resources for generating new sales opportunities across four types of customers', Industrial Marketing Management 68(1), 114-131. https://doi.org/10.1016/j. indmarman.2017.10.006

Nimako, S.G., Kwesi, F.B. \& Owusu, E.K., 2014, 'The impact of PLS-SEM training on faculty staff intention to use PLS software in a public university in Ghana', International Journal of Business and Economics Research 3(2), 42-49.

Nyangara, D., 2013, 'SME lending: Do lending technologies matter? Sample evidence from Zimbabwe', World Review of Business Research 3(4), 219-230.

O'Toole, T. \& McGrath, H., 2018, 'Strategic patterns in the development of network capability in new ventures', Industrial Marketing Management 70(1), 128-140. capability in new ventures', Industrial Marketing
https://doi.org/10.1016/j.indmarman.2017.07.003

Parida, V. \& Örtqvist, D., 2015, 'Interactive effects of network capability, ICT capability, and financial slack on technology-based small firm innovation performance' and financial slack on technology-based small firm innovation performance', journal of Sm.12191

Patel, P.C. \& Jayaram, J., 2014, 'The antecedents and consequences of product variety in new ventures: An empirical study', Journal of Operations Management 32(1) 34-50. https://doi.org/10.1016/j.jom.2013.07.002

Preacher, K.J., 2006 'Quantifying parsimony in structural equation modeling'. Multivariate Behavioral Research 41(3), 227-259.

Rakthin, S., Calantone, R.J. \& Wang, J.F., 2016, 'Managing market intelligence: The comparative role of absorptive capacity and market orientation', Journal of Business Research 69(12), 5569-5577. https://doi.org/10.1016/j.jbusres.2016.03.064

Ramon-Jeronimo, J.M., Florez-Lopez, R. \& Ramon-Jeronimo, M.A., 2017 'Understanding the generation of value along supply chains: balancing contro information and relational governance mechanisms in downstream and upstream relationships', Sustainability 9(1), 1487-1518. http://doi.org/10.3390/ su9081487

Rapp, A., Trainor, K.J. \& Agnihotri, R., 2010, 'Performance implications of customerlinking capabilities: Examining the complementary role of customer orientation and CRM technology', Journal of Business Research 63(11), 1229-1236. https:// doi.org/10.1016/j.jbusres.2009.11.002

Roy, R., Lampert, C.M. \& Stoyneva, I., 2018, 'When dinosaurs fly: The role of firm capabilities in the 'avianization' of incumbents during disruptive technological change', Strategic Entrepreneurship Journal 12(2), 261-284. https://doi. org/10.1002/sej.1278

Sekaran, U. \& Bougie, R., 2003, Research methods for business: A skill building approach, 5th edn., John Wiley \& Sons, Inc., New York, NY.

Shafique, M.N., Ahmad, N., Abbas, H. \& Hussain, A., 2015, 'The impact of customer relationship management capabilities on organizational performance; moderating role of competition intensity', Arabian Journal of Business and moderating role of competition intensity', Arabian Journal of Business and
Management Review (Nigerian Chapters) 3(3), 28-47. https://doi.org/ Management Review

Sharma, S.K. \& Govindaluri, S.M., 2014, 'Internet banking adoption in India: Structural equation modeling approach', Journal of Indian Business Research 6(2), 155-169. https://doi.org/10.1108/JIBR-02-2013-0013
Sigala, M., 2018, 'Implementing social customer relationship management: A process framework and implications in tourism and hospitality', International Journal of Contemporary Hospitality Management 30(7), 2698-2726. https://doi. org/10.1108/IJCHM-10-2015-0536

Smit, Y. \& Watkins, J.A., 2012, 'A literature review of small and medium enterprises (SME) risk management practices in South Africa', African Journal of Business Management 6(21), 6324-6330.

Soltani, Z. \& Navimipour, N.J., 2016, 'Customer relationship management mechanisms: A systematic review of the state of the art literature and recommendations for future research', Computers in Human Behavior 61(1), 667-688, https://doi. org/10.1016/j.chb.2016.03.008

Sulistyo, H. \& Siyamtinah, S., 2016, 'Innovation capability of SMEs through entrepreneurship, marketing capability, relational capital and empowerment', Asia Pacific Management Review 21(4), 196-203. https://doi.org/10.1016/j. apmrv.2016.02.002

Tavakol, M. \& Dennick, R., 2011, 'Making sense of Cronbach's alpha', International Journal of Medical Education 2(1),53-55. https://doi.org/10.5116/ijme.4dfb.8dfd

Tavani, S.N. Sharifi, H. \& Ismail, H.S., 2014 'A study of contingency relationships between supplier involvement, absorptive capacity and agile product innovation', International Journal of Operations \& Production Management 34(1), 65-92.

Teece, D.J., 2014, 'A dynamic capabilities-based entrepreneurial theory of the multinational enterprise', Journal of International Business Studies 45(1), 8-37. https://doi.org/10.1057/jibs.2013.54

Tumwine, S., Akisimire, R., Kamukama, N. \& Mutaremwa, G., 2015, 'A borrowing cost model for effective performance of SMEs in Uganda', World Journal of Entrepreneurship, Management and Sustainable Development 11(2), 74-89. https://doi.org/10.1108/WJEMSD-03-2014-0009

Tzokas, N., Kim, Y.A., Akbar, H. \& Al-Dajani, H., 2015, 'Absorptive capacity and performance: The role of customer relationship and technological capabilities in high-tech SMEs', Industrial Marketing Management 47(1), 134-142. https://doi. org/10.1016/j.indmarman.2015.02.033

Wang, M.C., Chen, P.C. \& Fang, S.C., 2018, 'A critical view of knowledge networks and innovation performance: The mediation role of firms' knowledge integration capability', Journal of Business Research 88(1), 222-233. https://doi. org/10.1016/j.jbusres.2018.03.034

Wang, Z. \& Kim, H.G., 2017, 'Can social media marketing improve custome relationship capabilities and firm performance? Dynamic capability perspective', Journal of Interactive Marketing 39(1), 15-26. https://doi.org/10.1016/j. intmar.2017.02.004

Xie, X., Zou, H. \& Qi, G., 2018, 'Knowledge absorptive capacity and innovation performance in high-tech companies: A multi-mediating analysis', Journa of Business Research 88(1), 289-297. https://doi.org/10.1016/j.jbusres.2018. 01.019

Yu, K., Cadeaux, J. \& Luo, B.N., 2015, 'Operational flexibility: Review and metaanalysis', International Journal of Production Economics 169(1), 190-202. https:// doi.org/10.1016/j.ijpe.2015.07.035

Yu, K., Luo, B.N., Feng, X. \& Liu, J., 2018, 'Supply chain information integration, flexibility, and : An archival search and content analysis', The International Journal of Logistics Management 29(1), 340-364.

Zulu-Chisanga, S., Boso, N., Adeola, O. \& Oghazi, P., 2016, 'Investigating the path from firm innovativeness to financial performance: The roles of new product success, market responsiveness, and environment turbulence', Journal of Small Business Strategy 26(1), 51-68. 